\title{
Severe Acute Pancreatitis Caused by Gallstones in a Young Adult
}

\author{
Ummi Maimunah*, Inne Tria Ramafita** \\ *Division of Gastroentero-hepatology, Department of Internal Medicine, \\ Faculty of Medicine, Universitas Airlangga/Dr Soetomo General Hospital, Surabaya \\ ${ }^{* *}$ Department of Internal Medicine, Faculty of Medicine \\ Universitas Airlangga/Dr. Soetomo General Hospital, Surabaya
}

\section{Coresponding author:}

Ummi Maimunah. Division of Gastroentero-hepatology, Department Internal Medicine, Universitas Airlanggal Dr. Soetomo Hospital. Jl. Mayjend Prof Dr Moestopo No. 6-8 Surabaya Indonesia. Phone: +62-31-5501614; facsimile:+62-31-5023865.E-mail: ummima@gmail.com.

\begin{abstract}
Acute pancreatitis is a pancreatic exocrine disorder consisting of various degrees of inflammation and is correlated with the parenchymal gland's damage due to auto-digestion of pancreatic enzymes. One of the causes of acute pancreatitis is gallstones. Acute pancreatitis has a typical clinical picture of abdominal pain with sedentary and blunt characteristics located in the epigastrium or periumbilical and often radiates to the back or chest, waist, and lower abdomen. Here presented a case of a 20-year-old male diagnosed with severe acute pancreatitis caused by gallstones who experienced various complications including acute necrotizing pancreatitis, colon perforation that caused generalized peritonitis and fistulation, as well as sepsis. The patient felt the main complaints, including intermittent abdominal pain, decreased appetite, nausea, and weakness. The treatment given is adequate conservative therapy and surgery for fluid and abscesses drainage, correction of fistulations, and perforation of hollow organs.
\end{abstract}

Keywords: sever acute pancreatitis, gallstones

\begin{abstract}
ABSTRAK
Pankreatitis akut merupakan gangguan dari eksokrin pancreas yang terdiri dari berbagai derajat inflamasi serta berhubungan dengan kerusakan kelenjar parenkim akibat autodigesti enzim pancreas. Salah satu penyebab pankreatitis akut adalah batu empedu. Pankreatitis akut memiliki gambara klinis yang khas yaitu nyeri perut dengan karakteristik menetap dan tumpul berlokasi di epigastrum atau periumbilikus dan sering menyebar kea rah punggung atau dada, pinggang, serta perut bagian bawah. Berikut disajikan kasus seorang pria berusia 20 tahun dengan diagnosis pankreatitis akut berat yang disebabkan oleh batu empedu serta memiliki berbagai komplikasi antara lain acute necrotizing pancreatitis, perforasi kolon yang menyebabkan peritonitis dan fistula, serta sepsis. Pasien merasakan keluhan utama antara lain nyeri perut menetap, penurunan nafsu makan, nausea, dan kelemahan. Perawatan yang diberikan adalah terapi konservatif yang cukup serta pembedahan untuk mengatasi drainase cairan dan asbes, koreksi terhadap fistula, dan perforasi organ berongga.
\end{abstract}

Kata kunci: pankreatitis akut berat, batu empedu 


\section{INTRODUCTION}

Acute pancreatitis is a pancreatic exocrine disorder consisting of various degrees of inflammation and is correlated with the parenchymal gland's damage due to auto-digestion of pancreatic enzymes. ${ }^{1}$ The incidence rate of acute pancreatitis ranges widely in different countries of the world. In the UK, the incidence rate is $56 / 100,000$ per year, while in the United States, more than 220,000 cases each year, where $20 \%$ of these cases are necrotizing pancreatitis with a mortality rate of $10 \% .{ }^{2,3}$ The spectrum of pancreatitis has several varieties, differing from interstitial pancreatitis with mild and self-limited manifestations to necrotizing pancreatitis with manifestations that arise depending on the severity of necrosis. ${ }^{2,4}$

There are various causes of acute pancreatitis in general, including gallstones (45\%), alcohol (35\%), hypertriglyceridemia (1-4\%), hyperparathyroidism, trauma, other diseases (10\%) such as infection, hypercalcemia, history of Endoscopic Retrograde Cholangiopancreatography (ERCP) (2\%), drugs intakes (2\%) such as 6-mercaptopurine, azathioprine, didanosine, valproate acid, ACE inhibitors, as well as mesalamine tumors that cause pancreatic duct obstruction and idiopathic (10\%)..$^{5-7}$

Acute pancreatitis has a typical clinical picture of abdominal pain with sedentary and blunt characteristics. The pain is located in the epigastrium or periumbilical and often casts towards the back or chest, waist, and lower abdomen. The pain grows worse in the lying position and when eating. Other complaints that can be found include nausea, vomiting, fever, abdominal distension, and jaundice if there is pressure from the intra-pancreatic bile duct. Besides, the Cullen's sign may appear as discoloration around the umbilicus and also Turner's sign if the discoloration occurs around the waist. On physical examinations, often found in severe acute pancreatitis are patients looking restless, anxious, decreased consciousness, and shock. ${ }^{4}$

\section{CASE ILLUSTRATION}

Mr. A, a 20-year-old man, was admitted to Dr. Soetomo General Hospital with the main complaint of intermittent abdominal pain that was felt from seven days before admitting to the hospital. He perceived pain in the gut and expanded to the upper right abdomen. He sometimes felt the pain penetrate his back. The pain continually occurred and was not related to any activities. The pain grew worse when he lay down and after eating and decreased when he sit down.
Other complaints were fever for five days earlier, decreased appetite, nausea, and body weakness since a week before admission to the hospital. No bleeding was found beneath the skin, no bluish skin throughout the abdomen, and no changes in bowel and urination patterns. There was also no previous history of trauma, diabetes mellitus, hypertension, or previous routine medication intake. He smoked approximately a pack every day and has stopped since he got sick. He never consumed alcohol.

Before admitted to Dr. Soetomo General Hospital, he underwent treatment at one of the hospitals in Surabaya. At that time, he was diagnosed with CBD (common bile duct) stone, acute pancreatitis, and acute kidney injury (AKI) with laboratory findings: Leukocytes $18,160 / \mathrm{mm}^{3}$; Neutrophils $83 \%$; BUN $110 \mathrm{mg} / \mathrm{dL}$; Creatinine Serum $7.37 \mathrm{mg} / \mathrm{dL}$; Amylase 397.90; Lipase 470.9; aspartate aminotransferase (AST) $300 \mathrm{IU} / \mathrm{L}$; alanine aminotransferase (ALT) 256 IU/L. The results of ultrasound and abdominal CT scans revealed acute pancreatitis with gallstones and pleural effusion. He was given four liters of rehydration fluid on the first day and three liters on the second day, followed by maintenance fluids and vasopressor drugs. Post-rehydration blood pressure on day 3 is 100/70 with a pulse of 96 times/minute. During the treatment, he underwent three hemodialysis with pre and post hemodialysis creatinine serum $10.3 \mathrm{mg} / \mathrm{dL}$ and 0.8 $\mathrm{mg} / \mathrm{dL}$, respectively. In the middle of the treatment, he felt the pain growing worse with permagna ascites. On the 25th day of treatment, he underwent an abdominal MRI examination and followed by MRCP. The results as shown in Figure 2 revealed acute necrotizing pancreatitis (ANP) with multiple cystic lesions containing fluid and peripancreatic fluid collection (PFC); a conservative therapy remained for him. On the 33rd day of treatment, the patient underwent an abdominal CT-Scan evaluation and the result showed the ANP was getting worse with PFC, which was increasingly expanding to suppress the stomach and surrounding organs, in addition to that stones at the end of the CBD were found. Furthermore, the patient underwent ERCP and performed CBD stent installation $(+/-7 \mathrm{~cm})$. Several times later, the patient underwent an abdominal CT-Scan re-evaluation because the complaints worsened, the results revealed that the abdominal wall was stiff and tense, and the patient had difficulty defecating. CT-scan results showed that an ANP with broader PFC was accompanied by a collection of colon-related air in flexural lienaldescendens (strongly suggestive colon perforation and 
peritonitis) as well as PFC fistulation with the colon. He later underwent laparotomy and external drain installation. A few days after surgery, the complaint became more severe, therefore he underwent an abdominal CT-Scan. The results showed that colon flexural lienalis perforations associated with PFC bags fistulated with the cavum peritoneum. There were also three external drains, two of them entered in PFC bags. Lastly, there was biller stents' migration to the duodenum. Then the patient was referred to Dr.

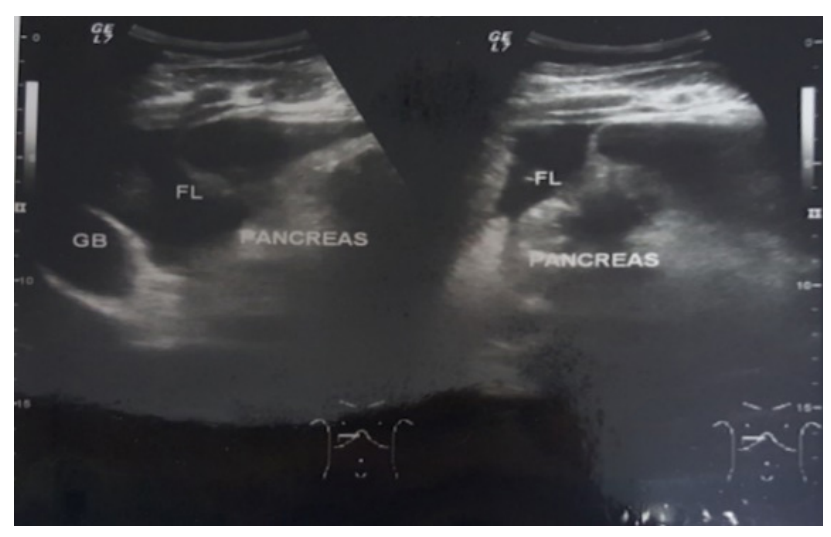

Figure 1. Ultrasound result showed sustained to acute pancreatitis, gall bladder stone $\&$ cholecystitis

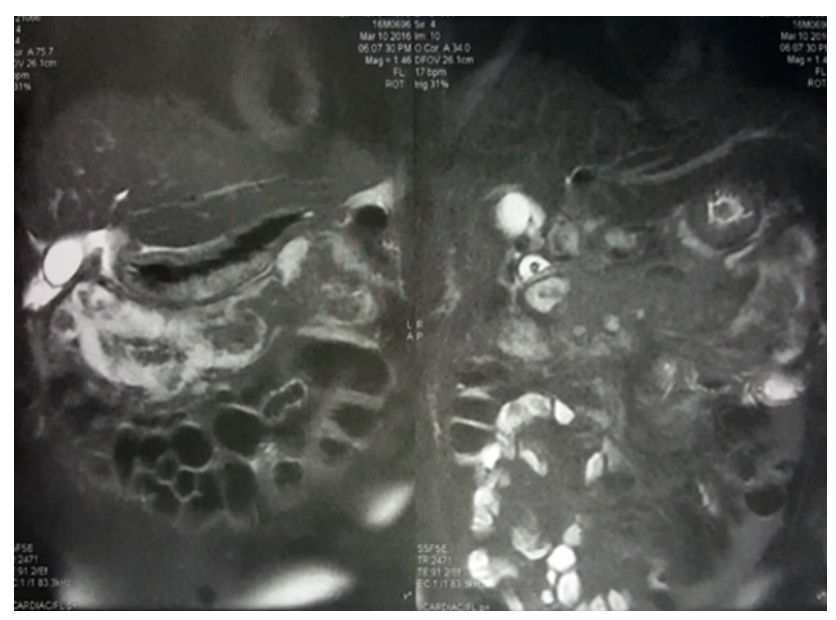

Figure 2. Abdominal MRI showed Acute Necrotizing Pancreatitis with multiple cystic lesions containing fluid and peripancreatic fluid collection (PFC)

Soetomo Hospital for further treatment.

On physical examination when the patient came to Dr. Soetomo Hospital, he was in a weak state, with compost mentis, GCS 15, blood pressure 130/80 $\mathrm{mmHg}$, pulse 110 times/minute, breath rate 24 times/ minute, and axillary temperature of $38.6^{\circ} \mathrm{C}$. From head and neck examinations obtained normal conjunctiva. No enlargement of the lymph nodes. The thorax examinations showed symmetrical breathing motion, single S1S2 heart sound, and in both lungs fields found vesicular breath sounds. No murmurs, gallop, or extrasystole, no retraction of breath-aiding muscles, no enlargement of the axillary lymph nodes, and no ronchi or wheezing. The abdominal examination showed decreased bowel sounds, distended with tenderness throughout the abdomen, liver and spleen were difficult to evaluate, tenderness in the epigastric and right upper quadrant (RUQ) regions, abdominal drain, and no Cullen or Turner sign. The extremities examinations revealed warm acral and edema in both legs. The VAS score is 7-8.

Laboratory findings include leukocytes $16,360 / \mathrm{mm} 3$; Neutrophils 80\%; Hb 12 g/dL; MCV 81; MCHC 32; Platelets 344,000/ $\mathrm{mm}^{3}$, albumin $3.3 \mathrm{~g} / \mathrm{dL}$; GDA $107 \mathrm{mg} /$ dL; BUN 6 mg/dL; SK 0.3 mg/dL; AST 50 U/L; ALT $70 \mathrm{U} / \mathrm{L} ; \mathrm{Na} 141 \mathrm{mmol} / \mathrm{L} ; \mathrm{K} 2.2 \mathrm{mmol} / \mathrm{L}$; Chloride 109 mmol/L; Amylase 334; Lipase 944; CRP $>120$. Blood gas analysis: $\mathrm{pH}$ 7.41; pO2 105; pCO2 37; $\mathrm{HCO} 322.4$; $\mathrm{BE}-1.2 ; \mathrm{SaO} 295 \%$. The radiology findings showed a plain thorax photo of AP: cast within normal limits, right pleural effusion, and tip shunt in vena cava superior at the level of Thorakalis Vertebrae 4.

\section{DISCUSSION}

Acute abdominal pain represents a spectrum of conditions varying from mild to severe and constitutes a surgical emergency. Evaluation of acute abdominal pain requires a comprehensive approach regarding the patient's complaint history, physical examination, and both laboratory and imaging examinations. ${ }^{8,9}$ One of the conceivably life-threatening causes of acute abdominal pain is acute pancreatitis. Pancreatitis is an inflammatory condition that causes pain in which pancreatic enzymes are activated prematurely, resulting in the pancreas autodigestive.

Based on guidance from the American College of Gastroenterology (ACG) in 2013, the diagnosis of acute pancreatitis is carried out if there are two of the following criteria: the presence of consistent abdominal pain, an increase of amylase serum and lipase more than three times higher than normal, and the presence of imaging examination results (ultrasound/CT-Scan/ MRI) that showed acute pancreatitis (10-12).

Some other indicators that also can be used as markers of severe acute pancreatitis include obesity, APACHE II score $\geq 8$ and evidence of organ failure when admitted to the hospital, $\mathrm{CRP} \geq 150 \mathrm{mg} / \mathrm{L}$ within 48 hours after admitted to the hospital, Glasgow score of more than 3 in 48 hours after admitted to the hospital, evidence of necrosis in CT-scan with contrast-enhanced, as well as procalcitonin value of more than $1.8 \mathrm{ng} / \mathrm{mL} .^{3}$

In this case, early clinical symptoms of abdominal pain were found one week before hospital admission, 
followed by nausea, general weakness, vomiting, fever, and flu-like syndromes. Laboratory findings showed amylase 397.90; Lipase 470.9 (which increased more than three times). Abdominal ultrasound and CTscan revealed an overview of acute pancreatitis with gallstones. Thus, this case met three diagnostic criteria based on ACG 2013 guidance.

Alcoholism and gallstones are the two main risk factors for acute pancreatitis. Gallstones can inhibit the outflow of bile and pancreatic fluid, which, if prolonged, can lead to acute pancreatitis. Alcohol consumption can reduce water and bicarbonate secretions as well as increase zymogen secretion from pancreatic acinar cells. This causes the pancreatic juice to become viscous and thick, potentially forming plugs and clogging the pancreatic ducts. ${ }^{13}$ The differential diagnosis of acute pancreatitis is considerably spacious, including mesenteric ischemia or infarction, gastric ulcer or duodenal perforation, biliary colic, aortic aneurysm, intestinal obstruction, and inferior myocardial infarction. ${ }^{9}$

In this case, there was no history of alcohol consumption, but the results of ultrasound imaging and CT scan showed cholelithiasis and blockages in the CBD due to gallstones. Thus, it can be presumed that in this case, the cause of acute pancreatitis is gallstones.

Assessment of the severity of acute pancreatitis is necessary to determine the prognosis, initial clinical management, and where the patient should be treated. Several parameters for assessing the severity of acute pancreatitis include, Revision Atlanta criteria with modified Marshall score, and the BISAP score.

The classification of acute pancreatitis based on the Revised Atlanta classification criteria, cited from Banks et al, is separated into three. First, mild acute pancreatitis where there is no organ failure and no local or systemic complications. The next is moderately severe acute pancreatitis if there are local complications and/or organ failure. Lastly, severe acute pancreatitis with persistent organ failure that occurs over 48 hours.

Meanwhile, as cited from Banks et al, the Modified Marshall scoring system is used to evaluate organ failure. The Marshall score calculation is completed by assessing at the dysfunction of the three criterion organs, namely, respiratory ( $\mathrm{PaO} 2 / \mathrm{FIO} 2)$, renal (serum creatinine, $\mathrm{mg} / \mathrm{dL}$ ), and cardiovascular (systolic blood pressure, $\mathrm{mmHg}$ ). Each criterion has its individual score. Score 0 if respiratory $<400$, renal $<1.4$, and cardiovascular $>90$. Score 1 if respiratory 301-400, renal 1.4-1.8, and cardiovascular $<90$ fluid responsive. Score 2 if respiratory 201-300, renal 1.9-3.6, and cardiovascular $<90$ not fluid responsive. Score 3 if respiratory 101-200, renal 3.6-4.9, and cardiovascular $<90$ with $\mathrm{pH}<7.3$. The last score is 4 if respiratory $\leq 101$, renal $>4.9$, and cardiovascular $<90$ with a $\mathrm{pH}$ $<7.2$. The score calculation is done by adding up the scores according to the patient's condition.

Patient in this case had a persistent renal failure ( $>48$ hours), with a Marshall score of 7 that persisted for longer than 48 hours with respiration of 175 and creatinine serum of $7.37 \mathrm{mg} / \mathrm{dl}$. Thus, according to Revised Atlanta Classification criteria 2013, the patient had a severe acute pancreatitis, and according to the Marshall score, was admitted to the intensive care unit.

A novel acute pancreatitis severity score system was recently developed, which is deemed more practical, namely using the bed site index acute pancreatitis (BISAP) score for the prognostic index. BISAP score is assessed based on five criteria: BUN more than $25 \mathrm{mg}$ /dL, impaired mental status, SIRS, patient's age is more than 60 years, and pleural effusion. Each criterion has a score of 1 . The BISAP score results are divided into three: BISAP score $<2$ has $0-0.5 \%$ mortality, BISAP score $=2$ has $2 \%$ mortality, while BISAP score $\geq 3$ has $5-20 \%$ mortality. ${ }^{11,14}$

In this case, based on the BISAP score, a score of 3 points was obtained, namely urea nitrogen $>125 \mathrm{mg}$ / $\mathrm{dL}$, pleural effusion, and the presence of the Systemic Inflammatory Response Syndrome (SIRS), fever with temperature of $38.5 \mathrm{C}$, leukocytes $35,000 / \mathrm{uL}$. Therefore, the BISAP score is 3, with mortality rates of $5-20 \%$.

Based on the accumulation of fluid due to acute pancreatitis complications and its anatomical pathology, acute pancreatitis can be classified into two types, namely necrotizing and edematous. Necrotizing pancreatitis is a severe form of acute pancreatitis characterized with parenchymal, peripancreatic, or combined necrosis in and around the pancreas identified by contrast-enhanced imaging. On the contrast, edematous pancreatitis is pancreatitis which lacks pancreatic or peripancreatic necrosis on imaging. ${ }^{15,16}$ Simultaneously, the complications that can be caused are divided based on the time of occurrence. ${ }^{17}$ The patient, in this case, was included as necrotizing pancreatitis type indicated by MRI and CT-scan results, which interpreted multiple cystic lesions containing fluid and peripancreatic fluid collection (PFC).

The therapy provided to severe acute pancreatitis is regularly conservative. Conservative therapies involve fluid resuscitation, nutrition, correction of electrolyte and coagulation disorders, analgesic administration, antibiotics administration if the indications are found, 
oxygen administration, and non-invasive and invasive ventilation.

Fluid resuscitation should be commenced promptly because fluid sequestration can occur within the first 48 hours. Fluid hydration is required aggressively as much as $250-500 \mathrm{cc} /$ hour using an isotonic solution with the presence of volume overload, pulmonary edema, and abdominal compartment syndrome in patients with comorbid heart or renal disease. Hydration monitoring of patients with comorbid heart or renal disease is suggested by measuring the central venous pressure through the central venous catheter (CVC) or measuring the intrathoracic blood volume index, which is more accurate compared to CVP. Body fluids requirements are assessed at 6-hour intervals for 24-48 hours with the target of decreasing hematocrit, BUN, creatinine, and urine production $>0.5 \mathrm{~mL} / \mathrm{kg} / \mathrm{h}$ ( $>500 \mathrm{cc} / 24$ hours). The administration of antibiotics in acute pancreatitis is carried out if there are signs of infection of the pancreas (infected necrosis) or extra pancreas (pneumonia, sepsis, cholangitis, UTIs, infections due to the use of catheters). Penicillin, first-generation cephalosporins, aminoglycosides, and tetracycline are ineffective in acute pancreatitis. Imipenem, clindamycin, piperacillin, fluoroquinolone, carbapenem, and metronidazole are broadly researched antibiotics that can decrease mortality and morbidity and penetrate into pancreatic organs. ${ }^{3,7}$ Imipenem use significantly reduces the incidence of acute necrosis pancreatitis. ${ }^{3}$ Most studies have shown that the use of prophylactic antibiotics to prevent infection in all acute pancreatitis cases shows no benefit, although some specialists still recommend the use of prophylactic antibiotics in ANP. ${ }^{18}$

Infection is a prevalent complication, especially in the ANP type. Inoculation of germs in the necrosis of the pancreas and peripancreatic can occur quickly. The germs that most frequently infect are germs due to the translocation of bacteria from the gastrointestinal tract. Bacteria from the gastrointestinal tract, such as Escherichia coli, Enterococcus faecalis, Acinetobacter baumanii, and Staphylococcus aureus, can infect the pancreas and encompassing areas that have necrosis. Symptoms of sterile and infected ANP are sometimes difficult to distinguish, therefore, it is essential to conduct bacteria and microbes culture test to diagnose infection and select the appropriate antimicrobial. Culture samples can be obtained from blood, urine, pseudocyst fluid, peripancreatic abscess fluid, and peritoneal fluid. ${ }^{19}$

Conservative therapy was given to the patient in this case. First, fluid resuscitation based on CVP as measured by CVC. The result of CVP measurement was $10 \mathrm{cmH} 2 \mathrm{O}$ so that it was continued with maintenance through CVC infusion of $1000 \mathrm{cc} / 24$ hours clinimix. Second, administration of antibiotics with intravenous cefoperazone sulbactam because of sepsis condition, but there was no clinical improvement. Thus the antibiotic was substituted with intravenous meropenem $3 \times 1 \mathrm{~g}$. According to the culture results, the antibiotic was substituted again with amikacin $1 \mathrm{x} 1 \mathrm{~g}$. After the clinical improvement, the patient was transferred to the regular treatment room. On the way, the patient again experienced signs of infection, so that the re-culture was done with ESBL results and sensitive to meropenem, antibiotics were then replaced with meropenem $3 \times 1$ g. After eight days of meropenem administration, the patient's clinical condition improved, and there were no signs of a distinct infection. The last therapy is intravenous analgesics administration.

Nutritional therapy in patients with severe acute pancreatitis is quite essential. Without proper nutritional support, morbidity and mortality will increase. Nowadays, the most recent guidelines recommend enteral nutrition as early as possible over parenteral nutrition. Early enteral nutrition can prevent gastrointestinal mucosal atrophy, prevent bacterial translocation, which is the most common cause of infectious complications in acute pancreatitis, and improve gastrointestinal motility in patients with ileus. A meta-analysis study by Al-Omran et al (2010) shows that enteral nutrition can reduce mortality, hospitalization duration, and the incidence of systemic infections. Data from the Python study in 1993 and approved by the study by Wu et al (2015) involving 1200 acute pancreatitis patients showed that the best time for enteral nutrition, if the patient can receive such intake, is 48-72 hours after onset. ${ }^{21}$ The provision of enteral nutrition can be through a nasogastric tube (NGT) or naso-jejunum tube (NJT). The provision of enteral nutrition is carried out gradually, starting in liquid and solid smooth and low-fat form. ${ }^{22}$

In this case, due to intra-abdominal infection and colon perforation complication as well as generalized peritonitis, the patient was fasted and received a parenteral diet (amino fluid 1000cc/24h, clinimix 1000 cc/24 hours, RD5 $1000 \mathrm{cc} / 24$ hours) and ivelip 2\% 100 $\mathrm{cc} / 3$ day. Patients did not receive an enteral diet after 48-72 hours of onset. However, after the complaints improved, enteral nutrition began to be given with a D5 liquid diet followed by a 6 x 50cc TKTP diet and raised gradually to $6 \times 250 \mathrm{cc}$. 
Several complications varying from mild to severe can occur in patients with acute pancreatitis. Complications that can generally occur can be classified into infective complications, vascular complications, gastrointestinal complications, and organ failure complications due to SIRS (Sethi \& Godhi, 2018; Singh et al, 2018). Peripancreatic fluid accumulation and pseudocyst formation are typical in acute pancreatitis. ${ }^{23}$ Infective complications include infection of the necrotic pancreatic tissue, typically 24-48 hours after the initial onset, leading to multi-organ failure with fatal consequences. Local necrotic tissue infection that occurs may proceed to the formation of a pancreatic/ peripancreatic abscess. Infection can also affect the fluid in the peripancreatic pseudocyst, which can cause severe inflammation and abscess formation. ${ }^{24}$ Vascular complications can include the formation of arterial pseudoaneurysms due to mechanical compression of the pancreatic mass or inflammatory erosions that regularly cause hemorrhagic processes in the pancreas and its surroundings. Although rare (1-2\%), venous thrombosis that befalls due to mechanical mass compression can occur in patients with acute pancreatitis. ${ }^{25,26}$

Gastrointestinal complications in acute pancreatitis cases can include obstruction caused by the gastrointestinal tract paralysis process resulting from SIRS or mechanical suppression of the peripancreatic mass. Gastrointestinal perforation due to prolonged obstruction and necrosis process caused by infection can also occur hence it can cause generalized peritonitis. If there is the adhesion of two organ walls and perforation, the creation of a fistula connecting the pancreas or pancreatic pseudocyst to the gastrointestinal tract may occur. This can aggravate the infection process and prolong healing. ${ }^{26}$ Severe systemic inflammatory processes that occur in acute pancreatitis with infection can also result in multiorgan damage, including acute prerenal renal failure, which require dialysis. ${ }^{27}$

In this case, complications were found in PFC infection form and pancreatic necrotic tissue, which caused sepsis and AKI, so the patient performed dialysis three times. Peripancreatic pseudocyst with increasing size was also found based on CT-scan result, SIRS sign with the source of subdiaphragmatic abscess infection, and colon perforation that causes generalized peritonitis and fistulation within pseudocysts PFC with colon enerdesendes and flexural lienalis.

Gallstones pancreatitis is a bile duct obstruction, which is the foremost cause of acute pancreatitis apart from alcohol use. Two plausible mechanisms of gallstones pancreatitis are biliary reflux into the pancreatic duct when the stone passes through the sphincter or reflux of enterokinase-containing duodenal fluid through the sphincter. Bile flow obstruction can cause disruption of the reticuloendothelial system in the liver, which can lead to severe pancreatitis. The urgent intervention for endoscopic retrograde cholangiopancreatography (ERCP) $(<48$ hours) in patients with acute pancreatitis is indicated if there is acute pancreatitis with cholangitis due to biliary obstruction and not indicated if there is no cholangitis and biliary obstruction. ${ }^{28}$ In patients with severe acute pancreatitis due to gallstones, cholecystectomy should be deferred to wait for the inflammatory process and necrosis to subside. The fittest time to perform cholecystectomy for it, especially with severe infection complications, is four weeks after the disease's onset. ${ }^{29}$ To prevent the recurrence of gallstones pancreatitis and ANP in patients with mild acute pancreatitis, cholecystectomy should be performed before the patient returns home. In patients who cannot perform surgery, the recurrence rate can be exceedingly reduced by endoscopic sphincterotomy. ${ }^{17}$

In this patient, due to local and systemic complications such as sepsis, ANP, suspected infected necrosis, and severe acute pancreatitis according to Revised Atlanta criteria, cholecystectomy was not performed at the time the patient was treated. ERCP to overcome biliary tract obstruction/CBD has also been performed with the installation of CBD stents (approximately 5 weeks after admitted to the previous hospital).

Operative action is a therapeutic modality for severe pancreatitis, which causes complications in massive pseudocyst formation, intra-abdominal abscess, fistula, and hollow organ perforation giving rise to generalized peritonitis. Drainage of the formed pseudocyst is indicated if there is a rupture of the enclosing organs, pain due to pressure from the pseudocyst, biliary and gastrointestinal obstruction due to mechanical pressure, growing volume, moreover bleeding and infection in the pseudocyst..$^{30}$ Drainage of fluids can be carried out internally (connected to the gastrointestinal lumen) or externally (removed to the outside)..$^{31,32}$ Drainage can be performed by percutaneous, perendoscopic and surgical drainage techniques. Percutaneous drainage is especially beneficial in fragile patients with severe comorbidities, who cannot endure surgical procedures or another endoscopy. On the other hand, percutaneous drainage has limitations such as the absence of a safe access route, active bleeding in the pseudocyst, and obstruction of the pancreatic duct, leading to fistula formation. Endoscopic 
drainage may also be performed with a higher likelihood of success, especially in the case of pseudocysts related to the pancreatic duct, but require adequate endoscopic staff skills and equipment and cannot be performed if the pseudocyst walls are too thick. Surgical drainage technique is an old method and is still used, especially in cases where other modalities fail or cannot be used as well as in cases of recurrent and progressive pseudocysts or other complications such as perforation, fistulation and abscess formation that require surgery. ${ }^{12,30}$

Treatment for abscesses that occur as a complication of ANP requires a combination of medical and surgical measures. Administration of antibiotics, as previously explained, is essential (especially for anaerobic and gram-negative bacteria). Pancreatic and peripancreatic abscess formation cases require both endoscopic and operative intervention. Although less invasive management such as the perendoscopic abscess drainage technique is preferred because it minimizes post-procedure complications, surgery may still be an option, especially in cases with extensive and complex pathological processes such as large pseudocysts, broad abscesses, fistulations, and colon perforations. ${ }^{33}$ In the case of infected ANP, in addition to an abscess, there can also be perforation of the hollow organs causing generalized peritonitis. Surgery is essential in this case. In this case, the internist's role is to diagnose organ perforation and strive for optimal conditions before surgery by surgical colleagues. ${ }^{33}$

In this patient, two laparotomy operations were performed. The first was performed while in the previous hospital with colonic perforation and external drain installation indications. The external drain was installed to reduce fluid stacks (PFC). After the surgery, colon perforation occurs approximately two months after the onset, and the patient declined to perform follow-up surgery when he was first referred and admitted to Dr. Soetomo General Hospital. On the 30th day of treatment, the patient underwent laparotomy to indicate colon perforation and sub diaphragm abscess drainage.

\section{REFERENCES}

1. Cahyono JSB. Tata Laksana Terkini Pankreatitis Akut. Medicinus 2014;27:43-50.

2. Boumitri C, Brown E, Kahaleh M. Necrotizing pancreatitis: Current management and therapies. Clin Endosc 2017;50:357-65.

3. Shah AP, Mourad MM, Bramhall SR. Acute pancreatitis: Current perspectives on diagnosis and management. J Inflamm Res 2018;11:77-85.

4. Fan B, Andrén-sandberg A. North American Journal of Medical Sciences Acute pancreatitis Background : Aims : Results : Conclusions 2010;2:211-4.
5. Economou M, Zissis M. Infectious cases of acute pancreatitis. Ann Gastroenterol 2000;13:98-101.

6. Banks PA, Bollen TL, Dervenis C, Gooszen HG, Johnson $\mathrm{CD}$, Sarr MG, et al. Classification of acute pancreatitis 2012: Revision of the Atlanta classification and definitions by international consensus. Gut 2013;62:102-11.

7. Tenner S, Baillie J, Dewitt J, Vege SS. American college of gastroenterology guideline: Management of acute pancreatitis. Am J Gastroenterol 2013;108:1400-15.

8. Cartwright SL, Knudson MP. Evaluation of acute abdominal pain in adults. Am Fam Physician 2008;77:971-8.

9. McNamara R, Dean AJ. Approach to Acute Abdominal Pain. Emerg Med Clin North Am 2011;29:159-73.

10. Manrai M, Kochhar R, Thandassery RB, Alfadda AA, Sinha SK. The Revised Atlanta Classification of Acute Pancreatitis: A Work Still in Progress? Limitations of the Original Atlanta Classification The Revised Atlanta Classification. J Pancreas 2015;16:356-64.

11. Maimunah U. Diagnosis dan Penatalaksanaan Pankreatitis Akut. In: SUDEMMA-13 Emergency and Severe GastroenteroHepatology Diseases. Surabaya: Fakultas Kedokteran Universitas Airlangga - RSUD Dr Soetomo; 2017.

12. DiMagno MJ, Mandalia A, Wamsteker EJ. Recent advances in understanding and managing acute pancreatitis. F1000 Res 2019;7:1-12.

13. Nesvaderani M, Eslick GD, Vagg D, Faraj S, Cox MR. Epidemiology, aetiology and outcomes of acute pancreatitis: A retrospective cohort study. Int J Surg 2015;23:68-74.

14. Gao W, Yang HX, Ma CE. The value of BISAP score for predicting mortality and severity in acute pancreatitis: A systematic review and meta-analysis. PLoS One 2015;10:1-15.

15. Shyu JY, Sainani NI, Anik Sahni V, Chick JF, Chauhan NR, Conwell DL, et al. Necrotizing pancreatitis: Diagnosis, imaging, and intervention. Radiographics 2014;34:1218-40.

16. Sabo A, Goussous N, Sardana N, Patel S, Cunningham SC. Necrotizing pancreatitis: A review of multidisciplinary management. J Pancreas 2015;16:90-4.

17. Lankisch PG, Apte M, Banks PA. Acute pancreatitis. Lancet 2015;386:85-96.

18. Serrablo A, Tejedor L, Martínez J. Antibiotics in severe acute pancreatitis. Central Eur J Med 2014;9:565-73.

19. Noor MT, Radhakrishna Y, Kochhar R, Ray P, Wig JD, Sinha SK, et al. Bacteriology of infection in severe acute pancreatitis. J Pancreas 2011;12:19-25.

20. Al-Omran M, AlBalawi ZH, Tashkandi MF, Al-Ansary LA. Enteral versus parenteral nutrition for acute pancreatitis. Cochrane Database Syst Rev 2010;28:1-46.

21. Krishnan K. Nutritional management of acute pancreatitis. Curr Opin Gastroenterol 2017;33:102-6.

22. Choudhary A, Bechtold ML, Arif M, Szary NM, Puli SR, Othman MO, et al. Pancreatic stents for prophylaxis against post-ERCP pancreatitis: A meta-analysis and systematic review. Gastrointest Endosc 2011;73:275-82.

23. Ahmed A, Gibreel W, Sarr MG. Recognition and Importance of New Definitions of Peripancreatic Fluid Collections in Managing Patients with Acute Pancreatitis. Dig Surg 2016;33:259-66.

24. $\mathrm{Lu} \mathrm{X}$, Aoun A. Complications of acute pancreatitis. Pract Gastroenterol 2012;10:1-19.

25. Dupuis CS, Baptista V, Whalen G, Karam AR, Singh A, Wassef $\mathrm{W}$, et al. Diagnosis and management of acute pancreatitis and its complications. Gastrointest Interv 2013;2:36-46. 
26. Sethi S, Godhi S. Complications of Acute Pancreatitis: Imaging Revisited. Gastroenterol Dig Syst 2018;5:234-42.

27. Singh M, Kathuria S, Saxena A, Kumar L, Jain S, Rasool S. Pancreatic Necrosis: A Challenging Complication of Acute Pancreatitis. Int Clin Pathol J 2018;6:13-7.

28. Vege SS, DiMagno MJ, Forsmark CE, Martel M, Barkun AN. Initial Medical Treatment of Acute Pancreatitis: American Gastroenterological Association Institute Technical Review. Gastroenterology 2018;154:1103-39.

29. Doctor N, Agarwal P, Gandhi V. Management of Severe Acute Pancreatitis. Indian J Surg 2012;74:40-6.

30. Agalianos C, Passas I, Sideris I, Davides D, Dervenis C. Review of management options for pancreatic pseudocysts. Transl Gastroenterol Hepatol 2018;2018:1-8.

31. Aghdassi A, Simon P, Pickartz T, Budde C, Skube ME, Lerch MM. Endoscopic management of complications of acute pancreatitis: an update on the field. Expert Rev Gastroenterol Hepatol 2018;12:1207-18.

32. Pan G, Wan MH u., Xie KL, Li W, Hu WM, Liu XB, et al. Classification and Management of Pancreatic Pseudocysts. Medicine (Baltimore) 2015;94:e960.

33. Kokosis G, Perez A, Pappas TN. Surgical management of necrotizing pancreatitis: An overview. World J Gastroenterol 2014;20:16106-12. 